\title{
PENGARUH KONSENTRASI DAN INTERVAL PUPUK ORGANIK CAIR TERHADAP PERTUMBUHAN SAMHONG (Brassica juncea L.) HIDROPONIK
}

\author{
Fatma \\ Program Studi Agroteknologi, Fakultas Pertanian dan Peternakan, Universitas Tjut Nyak Dhien, Medan \\ 20123, Sumatera Utara, Indonesia. \\ Iwan Saputra Harahap \\ Program Studi Agroteknologi, Fakultas Pertanian dan Peternakan, Universitas Tjut Nyak Dhien, Medan \\ 20123, Sumatera Utara, Indonesia. \\ Irna Marisa Siahaan \\ Program Studi Agroteknologi, Fakultas Pertanian dan Peternakan, Universitas Tjut Nyak Dhien, Medan \\ 20123, Sumatera Utara, Indonesia. \\ Yunida Berliana* \\ Program Studi Agroteknologi, Fakultas Pertanian dan Peternakan, Universitas Tjut Nyak Dhien, Medan \\ 20123, Sumatera Utara, Indonesia. Email: yd66berliana@gmail.com
}

\begin{abstract}
Abstrak
Penelitian ini bertujuan untuk mengetahui respon pertumbuhan tanaman samhong (Brassica juncea L,) terhadap pemberian Pupuk Organik Cair (POC) dengan konsentrasi dan interval pemberian yang berbeda pada budidaya secara hidroponik. Penelitian ini dilakukan pada Maret sampai Juli 2019 di Gang Eka Rosa, Jalan Eka Rasmi, Desa Johor, Kecamatan Medan Johor, Sumatera Utara. Metode penelitian menggunakan Rancangan Acak Lengkap faktorial terdiri dari factor pertama adalah konsentrasi POC yang terdiri dari 3 taraf perlakuan: $\mathrm{K} 1=1: 5 ; \mathrm{K} 2=1: 7,5$ dan $\mathrm{K} 3=1: 10$. Faktor kedua adalah interval pemberian POC yang terdiri dari 3 taraf perlakuan yaitu: $\mathrm{N} 1=$ setiap 2 hari, $\mathrm{N} 2=$ setiap 4 hari sekali dan N3= setiap 6 hari sekali. Hasil penelitian menunjukkan bahwa konsentrasi pupuk organik cair 1:10 (K3) dapat meningkatkan panjang daun $(13,60 \mathrm{~cm})$, bobot/perlakuan $(106,50 \mathrm{~g})$, dan bobot/tanaman samhong $(170,78 \mathrm{~g})$, namun berpengaruh tidak nyata terhadap lebar daun. Interval pemberian pupuk organik cair setiap 6 hari sekali (N3) signifikan meningkatkan panjang daun $(14,50 \mathrm{~cm})$, bobot/perlakuan $(108,81 \mathrm{~g})$, dan bobot/tanaman samhong $(170,98 \mathrm{~g})$. Interaksi kedua perlakuan ini berpengaruh tidak nyata terhadap semua parameter penelitian ini.
\end{abstract}

Kata Kunci: hidroponik, interval, konsentrasi, pupuk organik cair, tanaman samhong

\section{PENDAHULUAN}

Sayuran merupakan tanaman dengan kandungan gizi yang sangat dibutuhkan oleh manusia. Seperti halnya buah-buahan kandungan gizi dalam sayuran tidak kalah tinggi dalam hal meningkatkan kesehatan. Beberapa sayuran dapat dikonsumsi mentah sebagai lalapan dan selebihnya diolah terlebih dahulu menjadi masakan untuk mempergurih makanan.

Tanaman samhong (Brassica juncea L) merupakan salah satu tanaman sayuran yang memiliki tampilan daun yang agak keriting, lebar, berwarna hijau muda, dengan rasa yang renyah, serta memiliki khasiat yang baik bagi kesehatan karena kandungan berbagai gizi di dalamnya. Sayuran ini dapat dikonsumsi dalam keadaan mentah sebagai lalapan maupun setelah diolah menjadi masakan. Budidaya tanaman samhong merupakan usaha yang cukup menjanjikan bagi petani karena tanaman ini sudah dapat dipanen setelah berumur 45 hari.

Dalam peningkatan teknologi yang pesat di masyarakat, terutama masyarakat perkotaan, memudahkan setiap orang dalam mendapatkan ilmu pengetahuan. Kebutuhan masyarakat perkotaan akan konsumsi sayuran semakin beralih menuju tanaman organik, hal ini terjadi dengan ditemukannya berbagai resiko berbahaya dari tanaman-tanaman pertanian yang menggunakan pemupukan secara kimia. Namun budidaya tanaman ini di kota akan lebih optimal jika dilakukan secara hidroponik, karena selain keperluan lahan yang lebih sedikit, perawatan tanaman hingga panen juga lebih optimal (Hartus, 2008).

Budidaya hidroponik merupakan budidaya dengan menggunakan air sebagai media tumbuh tanaman. Beberapa kelebihan dalam budidaya secara hidroponik adalah penggunaan lahan yang lebih optimal karena media tanaman mudah disusun secara bertingkat, budidaya tanaman yang lebih homogen dengan meminimalkan pengaruh lingkungan serta pemberian nutrisi tanaman yang lebih mudah dengan hanya mencampurkan nutrisi ke dalam media penampungan untuk dialirkan ke seluruh tanaman.

Penggunaan pupuk dalam budidaya hidroponik memerlukan pupuk yang dapat dilarutkan dalam air agar bisa tercampur merata bagi semua tanaman dalam media. Pupuk tersebut dapat berupa pupuk kimia maupun pupuk organik. Pupuk organik merupakan pupuk yang berasal dari bahan-bahan organik yang berasal dari lingkungan yang kemudian diolah sedemikian rupa hingga tersedia 
bagi tanaman. Penggunaan pupuk organik pada budidaya tanaman hidroponik akan lebih efisien bila menggunakan pupuk organik cair (POC), agar bisa terlarut secara merata dalam media tanaman.

Pupuk Organik Cair (POC) merupakan salah satu pupuk organik yang telah banyak dikembangkan dalam masyarakat. POC memiliki kandungan berbagai jenis hara yang dibutuhkan tanaman baik makro dan mikro. Pembuatan pupuk ini cukup memerlukan biaya yang relatif murah karena menggunakan bahan-bahan organik sederhana yang ada dalam lingkungan dengan fermentasi kurang lebih selama sebulan hingga siap digunakan.

Dalam penelitian ini POC yang akan digunakan adalah hasil fermentasi dari bahan Urin Kelinci sebagai bahan utama dengan kandungan unsur hara makro yang tinggi.Bahan tambahannya adalah Rebung Bambu sebagai sumber unsur mikro, Air Kelapa sebagai sumber zat pengatur tumbuh (ZPT), EM4 sebagai mikroorganisme dalam fermentasi dan Molase sebagai sumber energi mikroorganisme selama fermentasi.

Pemupukan pada tanaman berbeda tergantung pada jenis tanaman tersebut. Pada tanaman Samhong dengan budidaya secara hidroponik memerlukan pemberian pupuk dengan konsentrasi dan interval pemupukan yang tepat. Hal ini sesuai dengan pendapat Buckman \& Brady, (1982) aplikasi pupuk yang berlebihan merupakan pemborosan dan bahkan dapat menyebabkan keracunan. Sedangkan pemberian dosis yang kecil tidak memberikan pengaruh yang signifikan terhadap pertumbuhan maupun produksi tanaman. Hasil penelitian Rajak et al., (2016) menunjukkan bahwa konsentrasi pemupukan POC BMW yang optimal pada tanaman sawi adalah 7,5 ml/l air dengan Interval waktu sekali 6 hari.

Tujuan penelitian ini untuk mengetahui respon pertumbuhan tanaman samhong (Brassica juncea L,) terhadap pemberian POC dengan konsentrasi dan interval pemberian yang berbeda pada budidaya secara hidroponik.

\section{METODE}

\section{Tempat dan Waktu Penelitian}

Penelitian ini dilaksanakan pada Maret sampai Juli 2019 di Gang Eka Rosa, Jalan Eka Rasmi, Desa Johor, Kecamatan Medan Johor, Kota Medan, Sumatera Utara, Indonesia.

\section{Bahan dan Alat}

Bahan yang dibutuhkan adalah benih tanaman samhong, urin kelinci, rebung bambu, EM4, molase dan air bersih. Alat yang dibutuhkan dalam penelitian ini adalah tong pembuatan POC, ember penampung nutrisi, media NFT dengan pipa 2,5 inchi dan 50 lubang tanam, mesin pompa, TDS, rockwool, kai flanel, cup hidropnik, solasi, kertas, spidol, dan alat-alat tulis lainnya.

\section{Rancangan Penelitian}

Penelitian menggunakan Rancangan Acak Lengkap (RAL) faktorial dengan 2 faktor perlakuan. Faktor pertama adalah konsentrasi POC yang terdiri dari 3 taraf perlakuan: $\mathrm{K} 1=1: 5 ; \mathrm{K} 2=1: 7,5$; dan $\mathrm{K} 3=1: 10$. Faktor kedua adalah waktu pemberian POC yang terdiri dari 3 taraf perlakuan: $\mathrm{N} 1=$ setiap 2 hari sekali, N2= setiap 4 hari sekali, dan N3= setiap 6 hari sekali.

\section{Pembuatan Pupuk Organik Cair}

Campurkan 1/2 botol EM4 dengan !/2 Liter molase dalam ember. Kemudian diamlan larutan selama satu jam agar bakteri EM4 kembali aktif. Dalam tong 601 masukkan urin kelinci $10 \mathrm{l}$, tambahkan $5 \mathrm{~kg}$ rebung bambu yang telah dicacah dan 21 air kelapa muda. Kemudian aduk seluruh bahan tersebut. Kemudian ke dalam tong yang telah berisi campuran urin kelinci, masukkan campuan EM4 secara perlahan sambil di aduk rata. Kedalam tong tersebut kemudian tambahhkan air hingga volume tong mencapai $50 \mathrm{l}$. Kemudian tutup rapat tong dan biarkan selama 2 minggu untuk fermentasi. Setiap pagi aduk campuran dalam tong ntuk mengeluarkan gas yang ada di dalamnya, kemudian tutup rapat kembali.

\section{Pembuatan Media NFT}

Sediakan 5 buah pipa bulat yang berukuran 2.5 inci dengan panjang $200 \mathrm{~cm}$. Buat lubang di pipa masingmasing sebanyak 10 lubang dengan jarak $20 \mathrm{~cm}$. Susun sejajar pipa-pipa tersebut menggunakan sambungan pipa dengan kemiringan yang sesuai dan rakit sedemikian rupa menjadi 3 tingkat. Letakkan pompa air dekat dengan rakitan dan sambungkan dengan rakitan tersebut. Di bagian bawah letakkan ember sebagai tempat pertukaran air yang keluar dan yang akan naik ke rakitan media NFT yang telah jadi. Kedalam setiap media NFT isikan air dan campuran POC dengan dosis sesuai perlakuan.

\section{Teknik Budidaya}

Budidaya tanaman dimulai dengan peyemain benih pada rockwool yang telah dipotong-potong. Masingmasing rockool disusun dalam wadah persegi setinggi 3 $\mathrm{cm}$ dan diisi dengan 1 benih. Selama penyemaian, siram tanaman dengan sprayer halus pagi dan sore dengan memperhatikan kelembapan media. Setelah tanaman berumur 2 minggu, masing-masing rockwool sudah dapat dimasukkan dalam cup hidroponik yang telah dipasang kain flanel. Kemudian masukkan masing-masing cup dalam lubang media NFT yang telah disediakan. Nyalakan pompa media. Perawatan tanaman diantaranya adala pemupukan dengan dosis sesuai perlakuan dan pennganan segera jika terdapat hama dan penyakit bagi tanaman. Panen dilakukan setelah tanaman berumur 45 hari dengan cara mengangkat tanaman dan memotong pangkal akar.

\section{Peubah Amatan}

Pengukuran panjang dan lebar daun tanaman dilakukan pada umur 2-5 Minggu Setelah Tanam (MST) pada 15 tanaman sampel dengan cara mengukur panjang pelepah daun paling bawah pada tanaman. Pengukuran bobot/tanaman dilakukan pada saat panen dengan cara menimbang masing-masing tanaman. Pengukuran bobot/perlakuan dilakukan pada saat panen dengan cara menimbang semua tanaman per perlakuan. Parameter dianalisis dengan sidik ragam dan dilanjutkan uji DMRT pada taraf $5 \%$. 


\section{HASIL DAN PEMBAHASAN Panjang Daun (cm)}

Hasil sidik ragam diperoleh bahwa interval pemberian POC berpengaruh sangat nyata terhadap panjang daun tanaman samhong umur 4 MST dan berpengaruh nyata pada umur 5 MST. Konsentrasi POC berpengaruh nyata terhadap panjang daun tanaman samhong umur 4-5 MST. Interaksi keduanya berpengaruh tidak nyata terhadap panjang daun tanaman samhong baik pada umur 2-5 MST (Tabel 1).

Tabel 1. Pengaruh konsentrasi, interval POC dan interaksinya terhadap panjang daun tanaman samhong umur 2-5 MST.

\begin{tabular}{|c|c|c|c|c|}
\hline Perlakuan & $\mathrm{K}_{1}$ & $\mathrm{~K}_{2}$ & $\mathrm{~K}_{3}$ & Rataan \\
\hline \multicolumn{5}{|c|}{2 Minggu Setelah Tanam } \\
\hline $\mathrm{N}_{1}$ & 3,70 & 2,97 & 3,51 & 3,39 \\
\hline $\mathrm{N}_{2}$ & 3,24 & 3,69 & 3,61 & 3,51 \\
\hline $\mathrm{N}_{3}$ & 3,27 & 3,05 & 3,03 & 3,12 \\
\hline Rataan & 3,40 & 3,24 & 3,38 & \\
\hline \multicolumn{5}{|c|}{3 Minggu Setelah Tanam } \\
\hline $\mathrm{N}_{1}$ & 7,23 & 7,30 & 7,42 & 7,32 \\
\hline $\mathrm{N}_{2}$ & 7,27 & 7,31 & 7,47 & 7,35 \\
\hline $\mathrm{N}_{3}$ & 7,93 & 7,88 & 7,43 & 7,75 \\
\hline Rataan & 7,48 & 7,50 & 7,44 & \\
\hline \multicolumn{5}{|c|}{4 Minggu Setelah Tanam } \\
\hline $\mathrm{N}_{1}$ & 9,28 & 9,49 & 10,31 & $9,69 \mathrm{cB}$ \\
\hline $\mathrm{N}_{2}$ & 9,26 & 10,77 & 11,65 & $10,56 \mathrm{bB}$ \\
\hline $\mathrm{N}_{3}$ & 11,75 & 13,33 & 13,25 & $12,78 \mathrm{aA}$ \\
\hline Rataan & $10,10 \mathrm{~b}$ & $11,19 \mathrm{a}$ & $11,74 \mathrm{a}$ & \\
\hline \multicolumn{5}{|c|}{5 Minggu Setelah Tanam } \\
\hline $\mathrm{N}_{1}$ & 10,31 & 10,71 & 11,93 & $10,98 \mathrm{c}$ \\
\hline $\mathrm{N}_{2}$ & 10,54 & 14,35 & 13,65 & $12,85 \mathrm{~b}$ \\
\hline $\mathrm{N}_{3}$ & 13,49 & 14,78 & 15,23 & $14,50 \mathrm{a}$ \\
\hline Rataan & $11,44 \mathrm{~b}$ & $13,28 \mathrm{a}$ & $13,60 \mathrm{a}$ & \\
\hline
\end{tabular}

Keterangan: angka yang diikuti oleh huruf yang sama pada baris dan kolom yang sama menujukkan berbeda tidak nyata pada DMRT taraf 5\% (notasi huruf kecil) dan $1 \%$ (notasi huruf besar).

Tabel 1 menunjukkan bahwa terjadi peningkatan panjang daun tanaman samhong seiring dengan peningkatan konsentrasi POC sampai 1:10 (K3) dan interval pemberian POC setiap 6 hari sekali (N3) pada umur 4-5 MST. Panjang daun tertinggi terdapat pada interaksi N3K3 sepanjang 15,23 cm.

\section{Lebar Daun (cm)}

Hasil sidik ragam diperoleh bahwa interval pemberian POC berpengaruh nyata terhadap lebar daun tanaman samhong umur 2-5 MST. Konsentrasi POC dan interaksinya berpengaruh tidak nyata terhadap panjang daun tanaman samhong umur 2-5 MST (Tabel 2).

Tabel 2 menunjukkan bahwa konsentrasi POC sampai 1:7,5 (K2) signifikan meningkatkan lebar daun tanaman samhong tertinggi $(7,62 \mathrm{~cm})$ dibandingkan konsentrasi lainnya sampai umur 5 MST. Interval pemberian POC setiap 4 hari sekali (N2) menunjukkan lebar daun tertinggi $(7,29 \mathrm{~cm})$ dibandingkan interval lainnya. Interaksi interval pemberian POC setiap 2 hari sekali dengan konsentrasi POC 1:10 (N1K3) menunjukkan lebar daun tertinggi $(8,71 \mathrm{~cm})$ dibandingkan interaksi lainnya.
Tabel 2. Pengaruh konsentrasi, interval POC dan interaksinya terhadap lebar daun tanaman samhong umur 2-5 MST.

\begin{tabular}{|c|c|c|c|c|}
\hline Perlakuan & $\mathrm{K}_{1}$ & $\mathrm{~K}_{2}$ & $\mathrm{~K}_{3}$ & Rataan \\
\hline \multicolumn{5}{|c|}{2 Minggu Setelah Tanam } \\
\hline $\mathrm{N}_{1}$ & 3,10 & 2,55 & 2,97 & $2,87 \mathrm{a}$ \\
\hline $\mathrm{N}_{2}$ & 2,69 & 3,01 & 3,13 & $2,94 \mathrm{a}$ \\
\hline $\mathrm{N}_{3}$ & 2,69 & 2,56 & 2,48 & $2,58 \mathrm{~b}$ \\
\hline Rataan & 2,83 & 2,70 & 2,86 & \\
\hline \multicolumn{5}{|c|}{3 Minggu Setelah Tanam } \\
\hline $\mathrm{N}_{1}$ & 4,63 & 4,99 & 4,31 & $4,65 \mathrm{ab}$ \\
\hline $\mathrm{N}_{2}$ & 4,21 & 5,35 & 5,79 & $5,12 \mathrm{a}$ \\
\hline $\mathrm{N}_{3}$ & 4,62 & 4,37 & 2,95 & $3,98 \mathrm{~b}$ \\
\hline Rataan & 4,49 & 4,91 & 4,35 & \\
\hline \multicolumn{5}{|c|}{4 Minggu Setelah Tanam } \\
\hline $\mathrm{N}_{1}$ & 5,09 & 6,59 & 6,59 & $6,09 \mathrm{ab}$ \\
\hline $\mathrm{N}_{2}$ & 5,93 & 7,31 & 7,85 & $7,03 \mathrm{a}$ \\
\hline $\mathrm{N}_{3}$ & 6,54 & 5,99 & 3,05 & $5,20 \mathrm{~b}$ \\
\hline Rataan & 5,85 & 6,63 & 5,83 & \\
\hline \multicolumn{5}{|c|}{5 Minggu Setelah Tanam } \\
\hline $\mathrm{N}_{1}$ & 5,54 & 7,21 & 8,71 & 7,16 a \\
\hline $\mathrm{N}_{2}$ & 6,57 & 8,13 & 8,17 & $7,62 \mathrm{a}$ \\
\hline $\mathrm{N}_{3}$ & 7,21 & 6,53 & 2,73 & $5,49 \mathrm{~b}$ \\
\hline Rataan & 6,44 & 7,29 & 6,54 & \\
\hline
\end{tabular}

Keterangan: angka yang diikuti oleh huruf yang sama pada baris dan kolom yang sama menujukkan berbeda tidak nyata pada DMRT taraf 5\% (notasi huruf kecil) dan $1 \%$ (notasi huruf besar).

\section{Bobot/Tanaman (g)}

Hasil sidik ragam diperoleh bahwa konsentrasi dan interval pemberian POC berpengaruh nyata, namun interaksinya berpengaruh tidak nyata terhadap bobot/tanaman samhong (Tabel 3).

Tabel 3. Pengaruh konsentrasi, interval pemberian POC dan interaksinya terhadap bobot/tanaman samhong.

\begin{tabular}{ccccc}
\hline Perlakuan & $\mathrm{K}_{1}$ & $\mathrm{~K}_{2}$ & $\mathrm{~K}_{3}$ & Rataan \\
\hline $\mathrm{N}_{1}$ & 160,27 & 170,30 & 170,42 & $170,00 \mathrm{~b}$ \\
$\mathrm{~N}_{2}$ & 170,27 & 170,31 & 170,79 & $170,46 \mathrm{~b}$ \\
$\mathrm{~N}_{3}$ & 170,93 & 170,88 & 180,12 & $170,98 \mathrm{a}$ \\
\hline Rataan & $167,16 \mathrm{~b}$ & $170,50 \mathrm{ab}$ & $170,78 \mathrm{a}$ & \\
\hline
\end{tabular}

Keterangan: angka yang diikuti oleh huruf yang sama pada baris dan kolom yang sama menujukkan berbeda tidak nyata pada DMRT taraf 5\% (notasi huruf kecil) dan $1 \%$ (notasi huruf besar).

Tabel 3 diatas menunjukkan bahwa perlakuan konsentrasi dan interval menunjukkan pengaruh yang nyata. Sedangkan pada interaksi antara kedua perlakuan menunjukkan pengaruh yang tidak nyata terhadap bobot/tanaman. Konsentrasi POC 1:10 (K3) menunjukkan bobot/tanaman tertinggi yaitu $17,78 \mathrm{~g}$ dan perlakuan interval yang tertinggi didapat pada N3 (6 hari) yaitu $17,98 \mathrm{~g}$.

\section{Bobot/Perlakuan (g)}

Hasil sidik ragam diperoleh bahwa konsentrasi dan interval pemberian POC berpengaruh nyata, namun interaksinya berpengaruh tidak nyata terhadap bobot/perlakuan (Tabel 4). 
Tabel 4. Pengaruh konsentrasi, interval pemberian POC dan interaksinya terhadap bobot/perlakuan.

\begin{tabular}{ccccc}
\hline Perlakuan & $\mathrm{K}_{1}$ & $\mathrm{~K}_{2}$ & $\mathrm{~K}_{3}$ & Rataan \\
\hline $\mathrm{N}_{1}$ & 72,86 & 89,25 & 80,09 & $80,73 \mathrm{~b}$ \\
$\mathrm{~N}_{2}$ & 88,26 & 90,07 & 111,18 & $96,50 \mathrm{~b}$ \\
$\mathrm{~N}_{3}$ & 97,07 & 101,15 & 128,22 & $108,81 \mathrm{a}$ \\
\hline Rataan & $86,06 \mathrm{~b}$ & $93,49 \mathrm{ab}$ & $106,50 \mathrm{a}$ &
\end{tabular}

Keterangan: angka yang diikuti oleh huruf yang sama pada baris dan kolom yang sama menujukkan berbeda tidak nyata pada DMRT taraf 5\% (notasi huruf kecil) dan $1 \%$ (notasi huruf besar).

Tabel 4 diatas menunjukkan bahwa perlakuan konsentrasi POC dan Interval pemberian berpengaruh nyata terhadap bobot/perlakuan. Interaksi antara kedua perlakuan menunjukkan pengaruh yang tidak nyata. Bobot tanaman/perlakuan yang tertinggi didapat pada konsentrasi K3 (1:10) yaitu 106,50 g sedangkan pada perlakuan interval pemberian didapat pada perlakuan N3 (6 hari) yaitu 108,81 g.

\section{Pengaruh konsentrasi pupuk organik cair terhadap pertumbuhan tanaman samhong}

Konsentrasi pupuk organik cair signifikan meningkatkan panjang daun, bobot/perlakuan, dan bobot/tanaman samhong, namun berpengaruh tidak nyata terhadap lebar daun. Hal ini disebabkan semakin tinggi konsentrasi pupuk organik cair sampai 1:10 maka semakin aktif pembelahan sel yang ditandai dengan pemanjangan daun tanaman samhong. Hal ini didukung literatur Lingga, (2008) menyatakan bahwa kandungan pupuk organik cair terdiri dari unsur hara makro N, P, dan $\mathrm{K}$ yang mempunyai peranan penting untuk pertumbuhan dan perkembangan tanaman. Peranan unsur $\mathrm{N}$ bagi tanaman adalah meningkatkan pem-bentukan klorofil, sintesis asam amino dan protein. Sarief, (2002) menyatakan bahwa meningkatnya jumlah klorofil akan meningkatkan laju fotosintesis sehingga fotosintat yang dihasilkan juga meningkat. Fotosintat tersebut selanjutnya digunakan untuk pertumbuhan vegetatif tanaman. Menurut Karnomo et al., (1990) unsur P mempunyai peranan yang penting dalam pembentukan akar, unsur $\mathrm{P}$ bersama-sama dengan unsur $\mathrm{N}$ dapat mendorong pemben-tukan akar dan rambut-rambut akar sehingga tanaman dapat menyerap unsur hara secara maksimal. Kondisi demikian akan berpenga-ruh terhadap meningkatnya pertumbuhan tanaman. Peranan kalium adalah katalisator dan stimulan dari beberapa proses fosforilasi, proses metabolisme karbohidrat, dan mengaktifkan enzim. Penelitian Surawinata et al., (2017) menyatakan bahwa bobot biji kering/petak terbaik diperoleh pada konsentrasi pupuk organik cair (Bio-agro) $10 \mathrm{ml} / \mathrm{l}$ yang diberikan pada Kultivar Vima-1 dengan menghasilkan produksi kacang hijau $0,38 \mathrm{~kg} /$ petak atau setara dengan 1,266 ton/ha. Wasis \& Badrudin, (2018) melaporkan bahwa konsentrasi pupuk organik cair berpengaruh sangat nyata terhadap tinggi tanaman, jumlah cabang/tanaman, panjang dan diameter buah, jumlah buah/tanaman, bobot buah/tanaman, jumlah dan panjang akar dengan pola pengaruh bersifat linier positif. Pertum-buhan dan produksi terung tertinggi diperoleh pada konsentrasi POC 22,5 ml/1 air. Triadiawarman \& Rudi, (2019) juga melaporkan bahwa dosis pupuk organik cair daun gamal memberikan pengaruh yang nyata terhadap tinggi tanaman $(8,332)$, jumlah daun $(7,911)$ dan berat segar $(7,027)$ tanaman sawi.

Pengaruh interval pemberian pupuk organik cair terhadap pertumbuhan tanaman samhong

Interval pemberian pupuk organik cair signifikan meningkatkan panjang daun, lebar daun, bobot/perlakuan, dan bobot/tanaman samhong. Hal ini menunjukkan adanya peran pemberian POC susulan dalam menambah kandungan unsur hara dalam media hidroponik Kandungan unsur hara dalam media akan berkurang karena diserap untuk pertumbuhan tanaman yang semakin meningkat. Hal ini sesuai dengan literatur Sutejo, (2002) menyatakan bahwa semakin bertambahnya umur pertumbuhan tanaman makin diperlukan pula pemberian unsur hara untuk proses pertumbuhan dan perkembangannya. Pemberian pupuk susulan berguna untuk menambah atau mengembalikan unsur hara tersebut. Dengan pemberian POC dapat meningkatkan ketersediaan dan serapan unsur hara terutama unsur hara $\mathrm{N}$ yang sangat diperlukan tanaman, sehingga tanaman dapat memacu pertumbuhan vegetatifnya. Daryanti \& Dewi, menyatakan bahwa interval pemberian pupuk organik cair berpengaruh nyata terhadap lebar daun terlebar dan berat kering tanaman, serta berpengaruh sangat nyata terhadap jumlah daun, berat segar tanaman dan berat konsumsi tanaman pakchoy dalam polibag. Triadiawarman \& Rudi, (2019) melaporkan bahwa interval waktu pemberian POC daun gamal 3 hari sekali signifikan meningkatkan tinggi tanaman sawi tertinggi $(8,076 \mathrm{~cm})$, jumlah daun tanaman tertinggi (7,683 helai), berat segar per tanaman tertinggi $(5,666 \mathrm{~g})$.

Interaksi konsentrasi dan interval pemberian pupuk organik cair terhadap pertumbuhan tanaman samhong

Interaksi konsentrasi dengan interval pemberian pupuk organik cair berpengaruh tidak nyata terhadap panjang daun, lebar daun, bobot/perlakuan, dan bobot/tanaman samhong. Hal ini disebabkan beberapa faktor luar yang mempengaruhi kurang efektifnya interaksi perlakuan.

\section{KESIMPULAN}

Konsentrasi pupuk organik cair 1:10 (K3) dapat meningkatkan panjang daun $(13,60 \mathrm{~cm})$, bobot/perlakuan $(106,50 \mathrm{~g})$, dan bobot/tanaman samhong (170,78 g), namun berpengaruh tidak nyata terhadap lebar daun. Interval pemberian pupuk organik cair setiap 6 hari sekali (N3) signifikan meningkatkan panjang daun $(14,50 \mathrm{~cm})$, bobot/perlakuan $(108,81 \mathrm{~g})$, dan bobot/tanaman samhong $(170,98 \mathrm{~g})$. Interaksi kedua perlakuan ini berpengaruh tidak nyata terhadap semua parameter penelitian ini.

\section{UCAPAN TERIMA KASIH}

Penulis mengucapkan terima kasih kepada Kementerian Riset, Teknologi, dan Pendidikan Tinggi yang telah mendanai penelitian ini melalui Program 
Kreativitas Mahasiswa Skema Penelitian Eksakta (PKMPE) pada Tahun 2019 dan kepada Universitas Tjut Nyak Dhien yang telah mendukung fasilitas penelitian ini.

\section{DAFTAR PUSTAKA}

Buckman H. O., dan Brady, N.C. 1982. Ilmu tanah. Bharata Karya Aksara: Jakarta.

Daryanti., dan Dewi, T. S. K. 2017. Pengaruh berat media dan interval pemberian pupuk cair terhadap pertumbuhan dan hasil tanaman pakchoy dalam polibag. Jurnal Ilmiah Agrineca, 17(2), 1-11. https://doi.org/10.36728/afp.v17i2.641.

Hartus, T. 2008. Berkebun hidroponik secara murah Edisi IX. PT. Agromedia Pustaka, Jakarta.

Karnomo, Soemedi, Dewanto, Widhiatmoko, Amirudin, Agusnirwanto. 1990. Pengantar Produksi Tanaman Agronomi. Fakulas Pertanian Universitas Jenderal Soedirman. Purwokerto.

Lingga, P. 2008. Petunjuk penggunaan pupuk. Penebar Swadaya. Jakarta

Rajak, O., Patty, J. R., dan Nendissa, J. I. 2016. Pengaruh dosis dan interval waktu pemberian pupuk organik cair BMW terhadap pertumbuhan dan produksi tanaman sawi (Brassica juncea L.). Jurnal Budidaya Pertanian, 12(2), 66-73. https://ojs3.unpatti.ac.id/index.php/bdp/article/view 1325 .

Sarief. 2002. Kesuburan dan pemupukan tanah pertanian. Pustaka Buana, Bandung.

Surawinata, E. T., Trisnaningsih, U., dan Panuntas, M. M. 2017. Pengaruh konsentrasi pupuk organik cair terhadap pertumbuhan dan hasil pada 3 (tiga) kultivar tanaman kacang hijau (Vigna radiata $\mathrm{L}$.). Agroswagati Jurnal Agronomi, 5(2), 620-634. http://dx.doi.org/10.33603/agroswagati.v5i2.1921.

Sutejo, M. 2002. Pupuk dan cara pemupukan. Bina Aksara, Jakarta.

Triadiawarman, D., dan Rudi. 2019. Pengaruh dosis dan interval waktu pemberian pupuk organik cair daun gamal terhadap pertumbuhan dan hasil tanaman sawi (Brassica juncea L.). Jurnal Pertanian Terpadu, 7(2), 166-172. https://doi.org/10.36084/jpt..v7i2.196.

Wasis., dan Badrudin, U. 2018. Pengaruh konsentrasi pupuk organik cair terhadap pertumbuhan dan produksi beberapa varietas tanaman terung (Solanum melongena L). Biofarm: Jurnal Ilmiah Pertanian, 14(1), 9-15. http://dx.doi.org/10.31941/biofarm.v14i1.786. 